\title{
METODE FADHLI FAME LANER UNTUK ALAT 3D LASER SCANNER
}

\author{
Fadhli Umar Lubis \\ Jurusan Teknik Mesin Fakultas Teknologi Industri Universitas Trisakti \\ E-mail: fadhli_umar@yahoo.com
}

\begin{abstract}
The 3D laser scanner that will be used in this study is a design tool for students of the 2007 Mechanical Engineering Department. This tool has been validated and used in several studies. Improvements to the 3D Laser Scanner tool are still being carried out, especially in the accuracy of the geometry of the 3D model produced and the time required in the processing of the scanning data. The research was conducted with the aim to increase the results obtained from the scanning process in order to have maximum results and have a fast processing time. In the research conducted, there are several differences with the previous method, namely the use of Visual Basic, supporting software, placing the camera and laser and camera settings. Based on the results of the study, the final results of the scan show the size of the test object has a smaller deviation of $8.12 \%$ for height, $0.8 \%$ for width and $19.3 \%$ for the neck, compared to previous studies of $61.09 \%$ for height, $51.8 \%$ for width and $40.75 \%$ for neck. For the time of the scanning process, there is a shortening of time that is very far compared to previous research, namely the time needed for 1 minute 56 seconds, while in the previous study it took 1 hour 41 minutes 37 seconds.
\end{abstract}

Keywords: 3D, Laser, Reverse, Scanner, Triangulation.

\begin{abstract}
Abstrak
$3 D$ laser scanner yang akan di gunakan pada penelitian ini merupakan alat hasil rancang bangun mahasiswa Jurusan Teknik Mesin 2007. Alat ini sudah divalidasi dan digunakan pada beberapa penelitian. Penyempurnaan pada alat 3D Laser Scanner tersebut masih terus dilakukan terutama dalam ketelitian geometri model 3D yang dihasilkan dan waktu yang diperlukan dalam proses pengolahan data hasil pemindaiannya. Penelitian dilakukan dengan tujuan untuk meningkatkan hasil yang di peroleh dari proses pemindaian agar memiliki hasil yang maksimal serta memiliki waktu pemrosesan yang cepat. Pada penelitian yang dilakukan, terdapat beberapa perbedaan dengan metode terdahulu yaitu penggunaan Visual Basic, software pendukung, peletakkan kamera dan laser serta setting kamera. Berdasarkan hasil penelitian, hasil akhir dari pemindaian menunjukkan ukuran benda uji memiliki penyimpangan lebih kecil yaitu sebesar $8.12 \%$ untuk tinggi, $0.8 \%$ untuk lebar dan $19.3 \%$ untuk leher, dibandingkan penelitian terdahulu sebesar $61.09 \%$ untuk tinggi, $51.8 \%$ untuk lebar dan $40.75 \%$ untuk leher. Untuk waktu proses pemindaian, terdapat penyingkatan waktu yang sangat jauh di banding dengan penelitian sebelumnya, yaitu waktu yang di perlukan selama 1 menit 56 detik, sedangkan pada penelitian terdahulu membutuhkan waktu 1 jam 41 menit 37 detik.
\end{abstract}

Kata kunci: 3D, Laser, Reverse, Scanner, Triangulation.

\section{Pendahuluan}

\section{Reverse Engineering}

Reverse Engineering adalah sebuah proses yang merupakan kebalikan dari Forward Engineering, untuk memahami kegiatan Reverse Engineering terlebih maka sebelumnya kita harus mengetahui tentang Forward Engineering, sebagai contoh Forward Engineering dapat kita lihat pada pembuatan mobil atau lain nya, dimana pembuatan disusun melalui proses analisa persyaratan, aerodinamis desain, sistem desain dan selanjutnya. Reverse Engineering pada dasarnya di sebut sebagai proses pemindaian 
(c) 2018 Pres Univ Press Publication, Indonesia objek real menjadi objek 3 dimensi untuk kemudian dilakukan proses lanjut pada software desain dan kemudian di produksi kembali.

\section{Scanner 3D}

Scanner 3D adalah sebuah perangkat yang mampu menganalisis sebuah objek 3D, dan mengumpulkan data tersebut untuk disusun menjadi sebuah model 3 dimensi. Perbedaan utamanya dengan scanner biasa ada pada kemampuannya menghasilkan image 3D. image 3D ini memungkinkan menghasilkan suatu bentuk point cloud geometris. Scanner 3D dapat dibedakan dari proses kerjanya menjadi 2 jenis, yaitu Contact 3D Scanner dan Non-Contact Scanner 3D.

\section{D Laser Scanner}

$3 D$ laser scanner merupakan alat $3 D$ scanner yang termasuk kedalam jenis peminadian non kontak dengan cara memanfaatkan pantulan sinar laser yang dipancarkan terhadap benda uji untuk tangkap oleh kamera dan diterjemahkan menjadi titik-titik koordinat. Menurut Pratama, 3D Laser Scanner atau lebih dikenal dengan sebutan laser scanner merupakan instrumen analisis objek real yang dapat mengumpulkan data permukaan dan bentuk objek kemudian ditampilkan dalam bentuk 3 dimensi. Tujuan dari suatu $3 D$ laser scanner adalah untuk menciptakan Point cloud dari permukaan objek dalam bentuk geometrik. Hasil scanning berupa Point cloud ini harus dibawa ke dalam suatu system, yaiut suatu proses yang biasa disebut registrasi, lalu digabungkan untuk menciptakan suatu model yang lengkap.

\section{Triangulasi 3D Laser Scanner}

3D laser scanner yang ada di universitas trisakti adalah alat 3D Laser Scanner yang memiliki konsep kerja scanner yang di sebut Triangulasi 3D Laser Scanner . 3D Laser Scaner triangulasi adalah salah satu jenis scanner yang menggunakan cahaya lasernya untuk proses pemindaiannya. Berkenaan dengan time-of-flight 3D Laser Scaner, pada metode triangulasi, laser menerangi suatu subyek dan memanfaatkan kamera untuk mencari lokasi titik laser. time-of-flight adalah salah satu teknologi dalam scanner, teknologi yang digunakan dalam scanner ini menggunakan cahaya laser untuk memeriksa subyek.

\section{Kamera.}

Kamera adalah alat paling populer dalam aktivitas fotografi atau membuat video. Kamera merupakan seperangkat alat yang memiliki fungsi untuk mengabadikan suatu objek menjadi sebuah gambar atau video yang merupakan hasil proyeksi pada sistem lensa. Kamera pada dasarnya memiliki berbagai macam jenis. Masing-masing jenis kamera di gunakan untuk aplikasi pemakaian yang berbeda, karena berbeda kamera maka berbeda juga standar spesifikasi dari kamera tersebut. Salah satu jenis kamera yang dipakai pada proses $3 D$ laser scanner di universitas Trisakti adalah jenis kamera webcam.

\section{Diafragma kamera webcam.}

Webcam (singkatan dari web camera) adalah sebutan bagi kamera real-time (bermakna keadaan pada saat ini juga) yang gambarnya bisa diakses atau dilihat melalui program video call atau lainnya. Komponen-komponen yang terdapat di dalam webcam, sama dengan komponen-kompone yang terdapat pada kamera lainnya. Masing-masing komponen memiliki fungsinya masing-masing. Salah satunya yang berpengaruh terhadap hasil yang di hasilkan pada kamera terutama kamera webcam adalah pembukaan dari diafragma kamera tersebut. Diafragma adalah komponen dari kamera yang mengatur banyak sedikitnya cahaya yang masuk atau yang ditangkap oleh kamera.

\section{Focal Length pada kamera}

Focal Length didefinisikan sebagai jarak dari pusat optik lensa ke titik fokus yang terletak pada sensor dalam satuan $\mathrm{mm}$. Atau secara gampang Focal Length adalah kemampuan sebuah lensa untuk menangkap suatu obyek. Baik objek lebar maupun objek sempit (mendetail) untuk ditangkap ke sensor \& diolah oleh kamera. Focal 
Journal of Mechanical Engineering and Mechatronics

ISSN: 2527-6212, Vol. 3 No. 1

(C) 2018 Pres Univ Press Publication, Indonesia

Length pada lensa kamera menentukan jenis dari lensa kamera tersebut. Berikut ini adalah pembagian jenis lensa kamera berdasarkan panjang dari Focal Length nya.

\begin{tabular}{|l|l|}
\hline Kurang dari $50 \mathrm{~mm}$ & Lensa Wide \\
\hline $50 \mathrm{~mm}$ & Lensa Normal \\
\hline Lebih dari $50 \mathrm{~mm}$ & Lensa Tele \\
\hline
\end{tabular}

\section{Metodologi Penelitian}

Proses 3D Laser Scanner dengan metode Fadhli Fame Laner.

Proses $3 D$ laser scanner dengan metode Fadhli Fame Laner meliputi diagram alir seperti berikut :
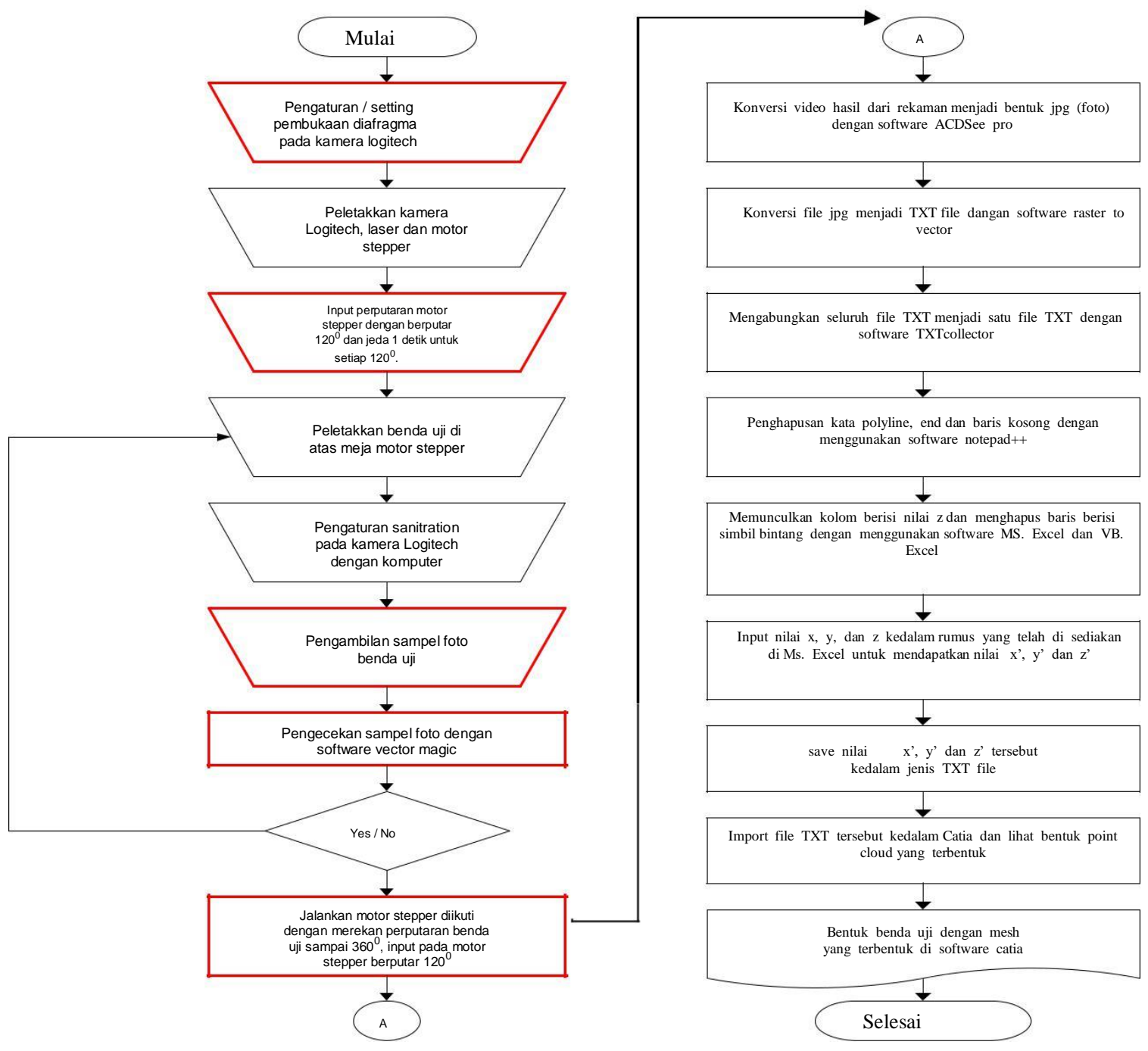


\section{Hasil dan Pembahasan}

Proses pemindaian 3D laser scanner dengan Fadhli Fame Laner memiliki tahapan tahapan yang berbeda dengan konsep dasar yang ada. Dalam Fadhli Fame Laner, ada beberapa software tambahan yang di gunakan dengan tujuan untuk mempercepat atau mempersingkat waktu dalam proses pemindaian $3 D$ laser scanner serta memaksimalkan hasil Point Cloud yang akan di bentuk.

Tahapan-tahapan keseluruhan pada proses pemindaian 3D Laser Scanner dengan Fadhli Fame Laner adalah sebagai berikut :

1. Atur terlebih dahulu pembukaan diafragma pada Kamera Logitech yang akan digunakan.

2. Atur peletakkan Kamera, Laser dan Motor Stepper.

3. Letakkan benda uji di atas meja putar Motor Stepper, dan di tengah meja putar Motor Stepper.

4. Atur sanitration pada kamera agar menghasilkan video dengan warna hitam putih.

5. Ambil sampel foto dengan Kamera Logitech. Ini di gunakan untuk mengetahui apakah hasil yang akan dihasilkan dari pantulan Laser sudah membentuk seluruh kontur benda uji dengan sempurna atau tidak. Pengecekan sampel foto dilakukan dengan menggunakan software Vector Magic.

6. Jika hasil dari sample foto sudah membentuk kontur benda uji dengan sempurna, maka selanjutnya jalankan Motor Stepper diikuti dengan kamera merekam pergerakan benda uji di atas rotor sampai rotor bergerak $360^{\circ}$. input Motor Stepper berputar dengan $120^{\circ}$ dan berhenti dengan jeda 1 detik.

7. hasil output dari kamera akan berupa video berjenis avi dengan durasi 13 detik.

8. konversi video avi tersebut kedalam file berjenis jpeg (foto) dengan software ACDsee Pro. File jpg yang dihasilkan akan berjumlah sebanyak 207 file.

9. Semua file jpeg hasil dan konversi kemudian di konversi kembali di konversi kedalam bentuk vektor dengan software Raster To Vector. File ouput akan berupa file berjenis TXT file.

10. Gabungkan seluruh file TXT file dari hasil konversi sebelumnya dengan software TXT collector. Pilih folder tempat menyimpan semua file TXT yang telah di peroleh dari hasil konversi sebelumnya dengan mengklik icon browse folder lalu, ceklis pilihan no filename serta isi * pada kotak select a separator or enter one. Dengan software ini seluruh TXT file akan menjadi satu dalam satu file TXT.

11. Buka file TXT yang telah di gabungkan dengan software Notepad++, dengan software ini hapus kata "polyline" dan "end" serta hapus "baris kosong" yang ada di dalam file tersebut.

12. Selanjutnya buka file tersebut dengan Ms. Excel. Masukkan rumus atau formula untuk memunculkan deret angka yang berurutan berdasarkan tanda bintang sebagai simbol tandanya.

13. Lalu hapus baris yang berisi simbol bintang pada cell $\mathrm{A}$ dengan VBA Ms. Excel yang telah di siapkan.

14. Cari modus untuk nilai $x$ dan $z$ dengan menggunakan formula mode yang terdapat di Ms. Excel.

15. Masukkan ketiga kolom yaitu kolom nilai sumbu $x, y$, dan $z$ yang telah di olah, ke dalam fungsi Ms. Excel yang telah di siapkan untuk memunculkan nilai sumbu x', y' dan z'. 
(C) 2018 Pres Univ Press Publication, Indonesia

Untuk metode Fadhli Fame Laner, jarak antara Tripod dengan titik tengah Motor Stepper adalah $28 \mathrm{~cm}$. Jarak $28 \mathrm{~cm}$ ini, di pilih setelah dilakukan 5 kali percobaan dengan merubah jarak antara tripod engan titik tengah Motor Stepper. 5 macam jarak percobaan terhadap Tripod dengan titik tengah Motor Stepper dalam metode Fadhli Fame Laner ini akan di bahas di bab berikutnya. Jarak akan mempengaruhi dimensi benda yang akan terbentuk di software Catia nanti. berikut ini adalah hasil dari 5 kali percobaan jarak tersebut.

kecepatan proses pemindaian dengan metode Fadhli Fame Laner ini dilakukan dengan menggunakan stopwatch. Stopwatch yang di pakai adalah Stopwatch yang tersedia di aplikasi Handphone Android. Pengambilan start dalam Stopwatch di ambil pada saat akan memulai tahap demi tahap. Berikut adalah perbandingan waktu yang di peroleh dari hasil penelitian :

\begin{tabular}{|c|c|c|c|c|c|c|c|c|}
\hline 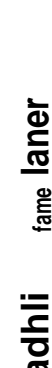 & $\begin{array}{l}\text { Peletakk } \\
\text { an } \\
\text { posisi } \\
\text { kamera, } \\
\text { laser } \\
\text { dan } \\
\text { stepper }\end{array}$ & $\begin{array}{l}\text { Waktu } \\
\text { pengola } \\
\text { ha } \\
\text { sampel } \\
\text { foto }\end{array}$ & $\begin{array}{l}\text { Waktu } \\
\text { konve } \\
\text { rsi } \\
\text { video } \\
\text { menja } \\
\text { di jpg }\end{array}$ & $\begin{array}{l}\text { Waktu } \\
\text { konve } \\
\text { rsi } \\
\text { dari } \\
\text { jpg } \\
\text { menja } \\
\text { vector }\end{array}$ & $\begin{array}{l}\text { Waktu } \\
\text { pengola } \\
\text { han } \\
\text { Di txt } \\
\text { collector }\end{array}$ & $\begin{array}{l}\text { Waktu } \\
\text { pengola } \\
\text { han di } \\
\text { notepad } \\
++\end{array}$ & $\begin{array}{l}\text { Waktu } \\
\text { pengola } \\
\text { han di } \\
\text { ms. } \\
\text { Excel }\end{array}$ & $\begin{array}{l}\text { Total } \\
\text { waktu } \\
\text { yang di } \\
\text { butuhk } \\
\text { an }\end{array}$ \\
\hline นீ & 30 detik & 20 detik & $\begin{array}{l}15 \\
\text { detik }\end{array}$ & $\begin{array}{l}15 \\
\text { detik }\end{array}$ & 3 detik & 18 detik & 2 detik & $\begin{array}{l}23 \\
\text { detik }\end{array}$ \\
\hline \multicolumn{6}{|c|}{ Total waktu yang di butuhkan } & \\
\hline
\end{tabular}

Kemudian, berikut ini adalah gambar hasil dari pemindaian dengan kelima jarak percobaan di atas. Gambar ini adalah gambar pada percobaan pertama untuk setiap jaraknya. Pada gambar di bawah ini, Point Cloud sudah di gabungkan menjadi mesh dengan software Catia V5.
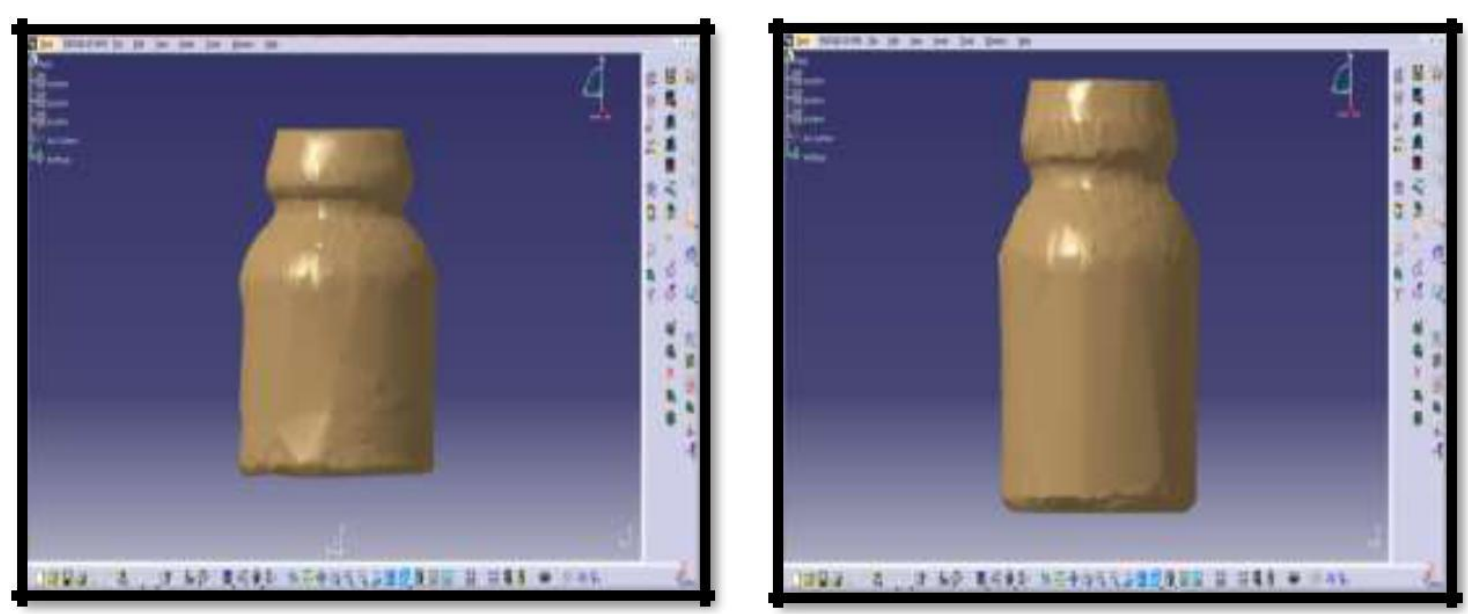
Gambar mesh pada jarak $21 \mathrm{~cm}$ (kiri), dan gambar mesh pada jarak $22 \mathrm{~cm}$ (kanan).
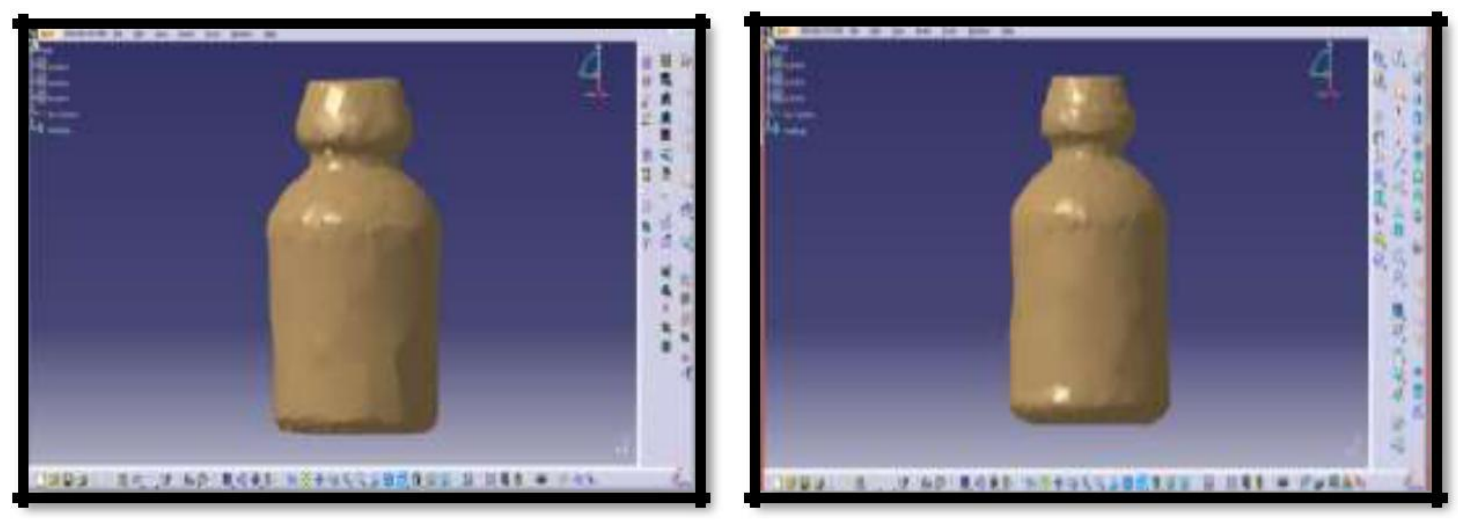

Gambar mesh pada jarak $24 \mathrm{~cm}$ (kiri), dan gambar mesh pada jarak $26 \mathrm{~cm}$ (kanan).

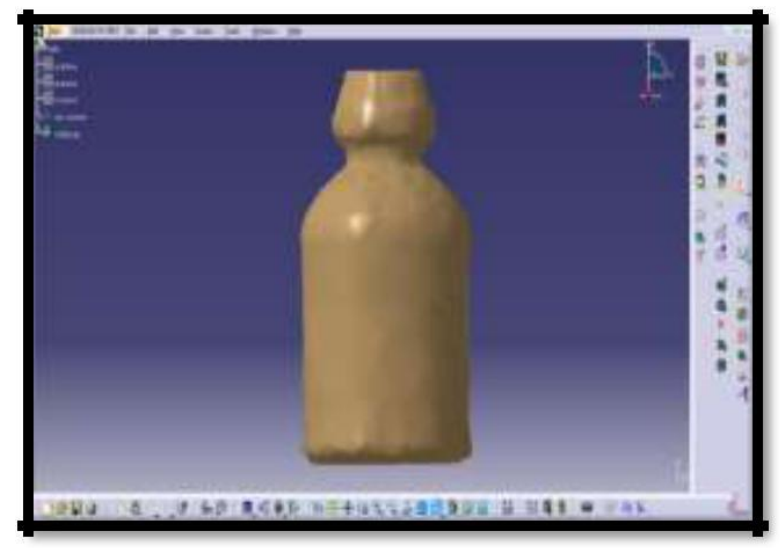

Gambar mesh pada jarak $28 \mathrm{~cm}$.

Pada ke lima gambar mesh di atas, dengan jelas dapat terlihat secara langsung terdapat perubahan dimensi benda yang terjadi secara beraturan untuk setiap penambahan jaraknya. Perubahan tinggi benda terjadi apa bila jarak di tambah, tetapi sebaliknya lebar benda akan semakin berkurang jika jarak di tambahkan.

\section{Kesimpulan}

1. Untuk waktu proses pemindaian, dengan metode Fadhli Fame Laner kecepatan waktu dari mulai peletakkan alat sampai ke proses akhir yaitu import file TXT ke software Catia memilki waktu yang cepat.

2. Untuk jarak yang tepat dalam pemindaian botol sun kline ini, dalam arti lain jarak yang menghasilkan tingkat kesalahan yang kecil pada metode Fadhli Fame Laner dipilih jarak $28 \mathrm{~cm}$.

3. Hasil yang di hasilkan dengan metode Fadhli Fame Laner memiliki kontur yang smooth hal ini dapat dilihat atau di cek dengan software Catia dimana pada metode Fadhli Fame Laner tidak terdapat kecacatan pada kontur benda yang di hasilkan.

4. Hasil yang di hasilkan dengan metode Fadhli Fame Laner memiliki tingkat penyimpangan dimensi yang lebih kecil. Untuk metode Fadhli Fame Laner memiliki tingkat penyimpangan sebesar, $8.12 \%$ untuk tinggi, $0.8 \%$ untuk lebar, dan $19.3 \%$ untuk leher. 
(C) 2018 Pres Univ Press Publication, Indonesia

5. Pembukaan diafragma sangat berpengaruh terhadap Point Cloud yang di hasilkan, yang nantinya akan di gabungkan menjadi mesh. Jadi, pengaturan pembukaan diafragma sangat di perlukan di karenakan Kamera Logitech yang di gunakan masih menggunakan pengaturan yang manual.

\section{Daftar Pustaka}

Axelsson, Peter, "Processing of laser scanner data-algorithms and applications", pp.138-139, Oktober 1998.

Agusthamb, Deny, "Distorsi", 10 Januari 2013, [Online]. Tersedia: http://askthephotographer. com/2013/10/distorsi.html. [Diakses : 10 Januari 2015]

Boy DB, "Analisis Faktor Koreksi 3D Laser Scanner Untuk Memindai Botol Persegi", 2010

Cahyati S, "Analisis Geometrik Ketelitian Sumbu Putar dan Kerataan Meja Putar 3D Laser Scanner", 2009

Cahyati S, "Analisis Ketelitian Posisi Henti Sesaat Pada Gerak Putar Meja Putar 3D Laser Scanner dengan Penggerak Motor Stepper", 2009.

Cahyati S, "The Geometrical Analysis of a Bottle CAD Modeling From 3D Laser Scanning Data Input”, 2009

Cahyati S, "Analisis Pembandingan Geometrik Model Non Silindris CATIA Hasil Scanning Mesin 3D Laser Scanner", 2011

Cahyati S, Lubis FU, dan Budiman M, "Rekayasa Program Bantu Untuk Mempersingkat Waktu Pengolahan Data Scan Model 3D Pada Teknologi Reverse Engineering", 2014

Saputra, Jimmy, "memahami focal length jarak focus lensa", 30 Januari 2013, [Online]. Tersedia : http://otodidakfotografi.blogspot.com/2013/01/memahami-focal-length-jarakfokus-lensa.html.[Diakses: 10 Januari 2015].

Muhardin, Rana Endy, "Memahami Lensa", 19 November 2013, [Online]. Tersedia : http://rana.endy.muhardin.com/gears/memahami-lensa. [Diakses: 10 Januari 2015]. 